\title{
Aplication of The Elaboration Model to Improve Mathematics Learning Outcomes of Class V Elementary Schools
}

\author{
Ade Sutisna \\ SD Negeri Panulisan Barat 01 \\ dedetriana@gmail.com
}

\section{Article History}

accepted 14/11/2020

approved $21 / 11 / 2020$

published 26/11/2020

\begin{abstract}
The purpose of this study was to improve the learning outcomes of class $V$ students in Mathematics learning with the elaboration learning model. The research undertaken was Classroom Action Research through 3 cycles, each cycle consisting of one meeting. The stages of each cycle are planning, implementing, observing, and reflecting. In the first cycle the learning completeness index was $77.78 \%$, in the second cycle and cycle it increased to $88.89 \%$. With the class average value of 77.78 in the first cycle, 87.04 in the second cycle and 87.78 in the third cycle. From this classroom action research, it can be concluded that the application of the elaboration learning model can improve student learning outcomes in learning Mathematics on the scale of SD Negeri Panulisan Barat 01, Dayeuhluhur District, Cilacap Regency.
\end{abstract}

Keywords: Elaboration Learning Model, Learning Outcomes

\section{Abstrak}

Tujuan dari penelitian adalah untuk meningkatkan hasil belajar peserta didik kelas $\mathrm{V}$ pada pembelajaran Matematika dengan model pembelajaran Elaborasi. Penelitian yang dilakuka adalah Penelitian Tindakan Kelas melalui 3 siklus, masing-masing siklus terdiri dari satu pertemuan. Tahapan setiap siklusnya adalah perencanaan, pelaksanaan, observasi, dan refleksi. Pada siklus I indeks ketuntasan belajar sebesar $77,78 \%$, pada siklus II dan siklus mengalami peningkatan menjadi $88,89 \%$. Dengan nilai rata-rata kelas 77,78 pada siklus I, 87,04 saat siklus II dan 87,78 pada siklus III. Dari penelitian tindakan kelas ini dapat disimpulkan bahwa penerapan model pembelajaran elaborasi dapat meningkatkan hasil belajar peserta didik pada pembelajaran Matematika materi skala SD Negeri Panulisan Barat 01 Kecamatan Dayeuhluhur Kabupaten Cilacap.

Kata kunci: Model Pembelajaran Elaborasi, Hasil Belajar

Social, Humanities, and Education Studies (SHEs): Conference Series https://jurnal.uns.ac.id/shes 


\section{PENDAHULUAN}

Peningkatan ilmu pengetahuan dan teknologi yang sangat pesat diera digital atau globalisasi ini mengakibatkan tuntutan dunia pendidikan semakin tinggi. Peningkatkan kualitas menjadi kebutuhan yang sangat penting untuk mengantisipasi perkembangan ilmu pengetahuan dan teknologi. Salah satu dari pengetahuan yang dimaksud adalah matematika.

Matematika merupakan ilmu pengetahuan dasar yang diberikan semenjak Sekolah Dasar sampai Sekolah Lanjutan Tingkat Atas, walaupun pada kenyataannya pendidikan matematika masih banyak mengalami masalah. Seperti yang peneliti alami pada saat pembelajaran matematika materi pokok skala yang terlihat dari hasil evaluasi peserta didik, dari 9 peserta didik hanya ada 4 peserta didik yang nilainya mencapai KKM. Hal ini disebabkan oleh kesulitan-kesulitan yang dirasakan oleh diri peserta didik dalam pembelajaran matematika, sehingga kadang peserta didik tidak tertarik dengan matematika.

Penggunaan metode dalam pembelajaran ikut berpengaruh terhadap hasil. Kenyataannya pelaksanaan pembelajaran di kelas, penggunaan metode pembelajaran yang bervariasi masih sangat jarang dilakukan dan guru cenderung menggunakan metode yang konvensional pada setiap pembelajaran. Hal ini disebabkan karena kurangnya penguasaan dan kecakapan guru terhadap metode maupun model-model pembelajaran yang ada.

Pada saat pembelajaran matematika peneliti telah berupaya semaksimal mungkin untuk memberikan informasi kepada peserta didik, namun setelah diadakan evaluasi hasilnya tidak sesuai dengan yang diharapkan.

Dengan kondisi tersebut maka dibutuhkan perubahan model dalam pembelajaran yang relevan yaitu dengan menggunakan model pembelajaran elaborasi. Untuk itu penggunaan model pembelajaran elaborasi diharapkan dapat meningkatkan hasil belajar dan minat peserta didik terhadap pembelajaran matematika materi pokok skala.

\section{METODE}

Penelitian ini adalah Penelitian Tindakan Kelas (PTK) dengan menerapkan model pembelajaran Elaborasi. Penelitian Tindakan Kelas ini terdiri dari empat tahapan yaitu perencanaan, pelaksanaan, observasi, dan refleksi. Analisis penelitian ini adalah analisis deskriptif kuantitatif kualitatif yaitu penyajian hasil penelitian berupa data, angka, dan analisis hasil penelitian menggunakan model Elaborasi. Subjek penelitian ini adalah peserta didik kelas V SD Negeri Panulisan Barat 01 Tahun Pelajaran 2020/2021 dengan jumlah peserta didik 9 orang yang terdiri dari 6 orang laki-laki dan 3 orang perempuan. Penelitian dilaksanakan selama tiga siklus secara luring dengan satu kali pertemuan pada setiap siklusnya. Siklus I dilaksanakan pada tanggal 26 Oktober 2020. Siklus II dilaksanakan pada tanggal 5 November 2020. Siklus III dilaksanakan pada tanggal 16 November 2020. Teknik pengumpulan data yang dilakukan adalah dengan observasi dan tes.

\section{HASIL DAN PEMBAHASAN}

Hasil penelitian tindakan kelas yang dilakukan di kelas V SD Negeri Panulisan Barat 01 pada pembelajaran Matematika materi pokok skala melalui tiga siklus dengan menggunakan model elaborasi, menunjukkan hasil yang maksimal. Setelah dilakukan analisis terhadap data yang diperoleh, hasil penelitian dapat dirangkum sebagai berikut:

Setelah dilakukan analisis terhadap data di atas, diketahui tingkat pemahaman peserta didik terhadap konsep "Menghitung Skala" setelah dilakukan perbaikan pembelajaran dengan menggunakan model pembelajaran Elaborasi menunjukkan hasil yang sangat signifikan. 
SHEs: Conference Series 3 (3) (2020) 908-912

Tabel 1Rekapitulasi Ketuntasan Belajar Peserta didik pada Setiap Siklus Kegiatan Perbaikan Pembelajaran.

\begin{tabular}{|c|c|c|c|c|c|c|}
\hline \multicolumn{7}{|c|}{ Hasil Belajar Peserta didik } \\
\hline & & Nilai & & & & \\
\hline NO & Pembelajaran & $\begin{array}{l}\text { Rata-rata } \\
\text { Kelas }\end{array}$ & Tuntas & Prosentase & Belum & Prosentase \\
\hline 1. & Studi Awal & 61,11 & 4 & $44,44 \%$ & 5 & $55,56 \%$ \\
\hline 2. & Siklus I & 77,78 & 7 & $77,78 \%$ & 2 & $22,22 \%$ \\
\hline 3. & Siklus II & 87,04 & 8 & $88,89 \%$ & 1 & $11,11 \%$ \\
\hline 4. & Siklus III & 87,78 & 8 & $88,89 \%$ & 1 & $11,11 \%$ \\
\hline
\end{tabular}

Dari tabel diatas diperoleh keterangan sebagai berikut :

1. Pada Kondisi awal, peserta didik yang tuntas belajar sebanyak 4 dari 9 peserta didik $(44,44 \%)$ dengan nilai rata-rata 61,11 .

2. Siklus I, peserta didik yang tuntas belajar sebanyak 7 dari 9 peserta didik $(77,78 \%)$ dengan nilai rata-rata 77,78 .

3. Pada siklus II, peserta didik yang tuntas belajar sebanyak 8 dari 9 peserta didik $(88,89 \%)$ dengan nilai rata-rata 87,04.

4. Pada siklus III, peserta didik yang tuntas belajar sebanyak 8 dari $9(88,89 \%)$ dengan nilai rata-rata 87,78 .

Sementara peserta didik yang belum tuntas belajar adalah sebagai berikut:

1. Pada kondisi awal, peserta didik yang belum tuntas belajar sebanyak 5 dari 9 peserta didik $(55,56 \%)$.

2. Pada siklus I, peserta didik yang belum tuntas belajar sebanyak 2 dari 9 peserta didik $(22,22 \%)$.

3. Pada siklus II, peserta didik yang belum tuntas belajar sebanyak 1 dari 9 peserta didik $(11,11 \%)$.

4. Pada siklus III, peserta didik yang belum tuntas belajar sebanyak 1 dari 9 peserta didik (11\%).

Nilai ketuntasan juga mengalami peningkatan dengan penjelasan sebagai berikut :

1. Pada siklus I, angka ketuntasan belajar peserta didik naik $33,34 \%$, mengalami penambahan peserta didik yang tuntas belajar sejumlah 3 siawa, yaitu dari 4 peserta didik menjadi 7 peserta didik.

2. Pada siklus II, angka ketuntasan belajar peserta didik naik $11,11 \%$, mengalami penambahan peserta didik yang tuntas belajar sejumlah 1 siawa, yaitu dari 7 peserta didik menjadi 8 peserta didik.

3. Pada siklus II, angka ketuntasan belajar peserta didik tetap seperti siklus II, yaitu jumlah yang tuntas 8 peserta didik. Namun rata-rata nilai kelas mengalami peningkatan dari dari siklus sebelumnya. $(87,04$ mnjadi 87,78$)$ 
Untuk lebih jelasnya peningkatan hasil belajar peserta didik dan nilai rerata dapat dilihat pada gambar diagram batang berikut ini :

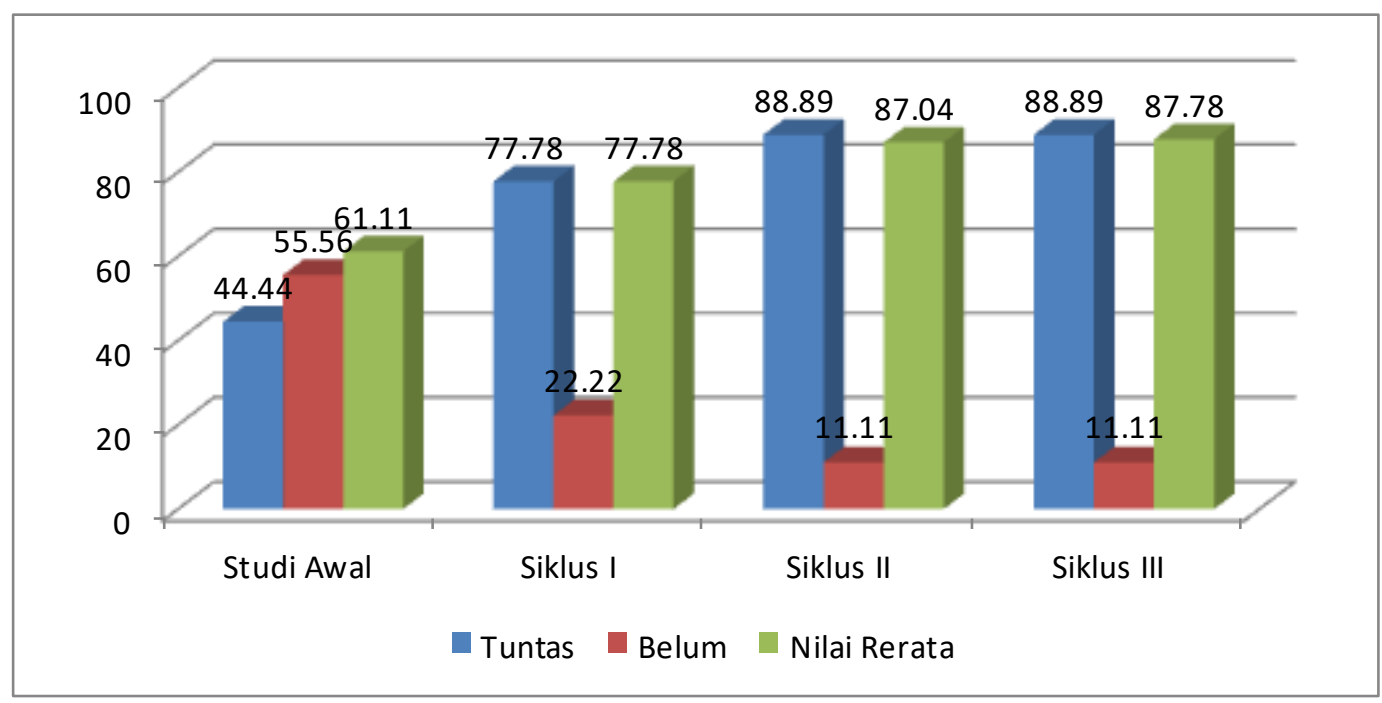

Gambar 1 Diagram Batang Perbandingan Angka Ketuntasan, Ketidak Tuntasan, dan Nilai Rerata pada Setiap Siklus Kegiatan Perbaikan Pembelajaran.

Pemilihan alternatif pemecahan masalah dengan penerapan model pembelajaran elaborasi untuk meningkatkan hasil belajar peserta didik kelas V SD Negeri Panulisan Barat 01 pada pembelajaran Matematika materi Skala dapat meningkatkan hasil belajar peserta didik jika dibandingkan dengan pembelajaran sebelumnya. Dengan penerapan model pembelajaran elaborasi juga dapat meningkatkan efektifitas pembelajaran dan meningkatkan motivasi peserta didik dalam mengikuti pembelajaran yang inovatif berbasis HOTS. Karakter peserta didik kelas V sangat sesuai jika melakukan pembelajaran matematika dengan model pembelajaran elaborasi yang memiliki karakteristik pembelajaran dari umum menuju rinci.

\section{SIMPULAN}

Berdasarkan analisis data dan beberapa temuan dapat ditarik kesimpulan bahwa penggunaan model Elaborasi pada pembelajaran Matematika materi pokok skala dapat meningkatkan hasil belajar peserta didik yang ditunjukkan dengan ketuntasan pada studi awal hanya 4 peserta didik atau $44,44 \%$, meningkat menjadi 7 peserta didik atau $77,78 \%$ saat siklus I, 88,89\% atau 8 dari 9 peserta didik pada siklus II, dan siklus III. Hal ini terjadi karena karakteristik model pembelajaran Elaborasi mengarahkan peserta didik untuk (1) belajar dari hal yang umum menuju hal yang lebih rinci; (2) membiasakan peserta didik mengerjakan tugas-tugas yang bermakna; (3) Memfasilitasi peserta didik melalui pemberian tugas, diskusi, dan lain-lain untuk memunculkan gagasan baru baik secara lisan maupun tertulis; Memberi kesempatan untuk berfikir dan bertindak tanpa rasa takut;(4) Memfasilitasi peserta didik dalam pembelajaran kooperatif; (5) Memfasilitasi peserta didik berkompetisi secara sehat untuk meningkatkan prestasi belajar. Diakhir penelitian masih terdapat 1 dari 9 peserta didik yang belum memenuhi Kriteria Ketuntasan Minimal (KKM) dan memerlukan bimbingan lanjutan. 
DAFTAR PUSTAKA

Lie, Anita. (2004). Mempraktikkan Cooperative Learning di Ruang-ruang Kelas. Jakarta: Grasindo.

Mikarsa, H.L, Taufik, A, Prianto, P.L. (2007). Pendidikan Anak SD. Jakarta: Universitas Terbuka.

Muhsetyo, Gatot, dkk. (2007). Pembelajaran Matematika SD. Jakarta: Universitas Terbuka.

Ristata, R dan Prayitno. (2006). Panduan Penelitian Laporan Penelitian Tindakan Kelas. Purwokerto: UPBJJ Purwokerto.

Slameto. (2003). Belajar dan Faktor-faktor yang Mempengaruhinya. Jakarta: Rineka Cipta.

Slavin, R.E. (2009). Cooperative Learning Teori, Riset dan Praktik. Bandung: Nusamedia.

Suharsimi, Arikunto. (1997). Prosedur Penelitian Suatu Pendekatan Praktek. Jakarta: Rineka Cipta.

Prabowo, Arief. 2009. Penerapan Model Pembelajaran Elaborasi (Diakses): http://eprints.ums.ac.id/7195/1/A410050066 